Hispania, 2016, vol. LXXVI, nº. 253, mayo-agosto, págs. 415-444

ISSN: 0018-2141, e-ISSN: 1988-8368, doi: 10.3989/hispania.2016.013

\title{
El negocio del siglo. Los judeoconversos y la renta de la seda del Reino de Granada (siglo XVI)*
}

\author{
Enrique Soria Mesa \\ Universidad de Córdoba \\ hi2hisal@uco.es
}

RESUMEN: La renta de la seda de Granada fue uno de los principales impuestos españoles durante la Época Moderna. La investigación en que se basa este artículo demuestra que la gran mayoría de los arrendadores de impuestos que encontramos en su gestión fueron parientes cercanos entre sí. Además, todos ellos fueron judeoconversos que no sólo se enriquecieron con esta actividad económica, sino que la utilizaron para progresar socialmente.

\section{Palabras Clave: Reino de Granada; Seda; Judeoconversos; Paren- tesco.}

The business of the century. The «Judeoconversos» and the Renta de la Seda in the Kingdom of Granada (XVI ${ }^{\text {th }}$ century)

ABSTRACT: The renta de la seda in Granada was one of the most relevant taxes in Early Modern Spain. The research in which this article is based on, shows that most of the tax farmers involved in managing the "Renta de la Seda» were close relatives. Furthermore, all of them were «judeoconversos» and took advantage of this economic activity not only to enrich themselves but also to progress in society.

KEY WORDS: Kingdom of Granada; Silk; «Judeoconversos»; Kinship.

* Abreviaturas: Archivo de la Curia Diocesana de Granada (ACuG), Archivo Diocesano de Sevilla (ADS), Archivo de la Diputación de Granada (ADG), Archivo Histórico Nacional (AHN), Archivo General de Indias (AGI), Archivo General de Simancas (AGS), Archivo de la Real Chancillería de Granada (ARChG), Archivo de Protocolos del Colegio Notarial de Granada (APG). Este trabajo se inscribe en el marco del proyecto de investigación «Nobles judeoconversos (II)». La proyección patrimonial de las élites judeo conversas andaluzas (HAR2015-68577), financiado por el Ministerio de Economía y Competitividad. 


\section{LA RENTA DE LA SEDA}

La importancia que tuvo la producción y la comercialización de la seda en el emirato nazarí y posteriormente en el reino castellano de Granada sólo es comparable a la gran transcendencia de la renta de la seda, la particular tributación ejercida por el estado cristiano sobre el producto de carácter suntuario. Una de las principales elaboraciones artesanales de Granada, y por ende de toda la Península, es tema aparentemente bien conocido en sus rasgos generales. Y desde hace tiempo, pues llamó tanto la atención de los grandes historiadores de la economía del siglo pasado como de especialistas locales.

La Renta de la Seda, concretamente, ha sido uno de los principales campos de análisis de los investigadores que se han acercado a la cuestión, debido por supuesto a la gran importancia que tuvo en el concierto del erario regio de los Habsburgo. En un inicio, a través de las frías relaciones contables del Archivo General de Simancas. Más adelante, mediante el estudio del impacto local de unas contribuciones en ocasiones más que excesivas, insertas en el delicado juego de poder entablado en las tierras meridionales del Imperio entre moriscos y cristianos viejos.

Sin embargo, más allá de cuentas, cifras y fechas, prácticamente nada se sabe de los protagonistas del arrendamiento de una de las principales rentas de la Corona española. Conocemos sus nombres, y los estudios más recientes parecen haber completado la nómina de los arrendatarios. Mas de ellos, denominaciones aparte y en algunos casos su oriundez, prácticamente nada sabemos. Ni de su origen social, su procedencia étnico-religiosa, su genealogía y contexto familiar, sus relaciones entre sí, que casi siempre las hubo aunque han pasado desapercibidas prácticamente en su totalidad.

Dicho de otro modo, hace falta un estudio social de la Renta de la Seda de Granada, centrado en los protagonistas de los colosales arrendamientos a que su gestión dio lugar. Y que haga hincapié en el factor judeoconverso a ella asociado, algo clave como veremos pero que ha sido ocultado por la larga sombra de los moriscos. Una vez más, la historia del reino granadino, que tiene como eje a la población de origen islámico, ha dejado en la penumbra el muy relevante aporte de los otros cristianos nuevos, los de progenie hebrea, que tanta trascendencia tuvieron. Y que en este caso, protagonizaron por completo esta particular parcela económica. Veámoslo.

\section{ESTADO DE LA CUESTIÓN}

Tras una larga etapa de abandono historiográfico, a mediados del siglo XX emerge con luz propia la Renta de la Seda de Granada como un tema digno de 
estudio. Y curiosamente no lo hace, como hubiera sido lo lógico, emanando de los estudios de eruditos locales o de profesores de la Universidad granadina, sino que los investigadores que la empiezan a situar en el mapa son foráneos al territorio o incluso extranjeros.

Obras como Los Banqueros de Carlos $V$ de Ramón Carande dedican un buen espacio a la seda de Granada, y lo mismo sucede con la continuación de sus estudios hacendísticos, esta vez de mano de Modesto Ulloa ${ }^{1}$. En ambos casos, los respectivos autores son plenamente conscientes de la trascendencia que tuvo este impuesto particular en el conjunto de las rentas del estado castellano durante el siglo XVI. Por fechas parecidas estaba editando un documentado estudio sobre la cuestión, pero desde la órbita malagueña, Francisco Bejarano Robles ${ }^{2}$, mientras que un interesante artículo del hispanista Kenneth Garrad ponía en relación la crisis de la seda con el levantamiento morisco de las Alpujarras y la extensión de la rebelión a lo largo de todo el territorio del antiguo emirato nazarí ${ }^{3}$. Todo ello, del mayor interés, pero aún así se trata de estudios limitados en cuanto a su ambición y sus aportaciones; sin embargo, el camino a seguir ya estaba trazado.

Un cuarto de siglo después comienzan a proliferar estudios de mayor calado sobre la seda de Granada, por un lado, y sobre la renta derivada de tal producción manufacturera y tráfico comercial. Es entonces cuando surge el libro clásico, de todos citado, de Manuel Garzón Pareja sobre la industria sedera de Granada, obra que debido a su deficiente distribución editorial no ha tenido el impacto que mereciera ${ }^{4}$.

Años después, sobre todo en la década de los noventa del siglo pasado, diferentes investigadores del ámbito medievalista y modernista fueron realizando aportaciones de diverso calado sobre el tema. Así, Ladero Quesada, Vera Delgado, Torres Fernández, Castillo Fernández y Muñoz Buendía...5 . A destacar entre todos ellos las excelentes interpretaciones del fenómeno, situadas en su adecuado contexto, de José Enrique López de Coca Castañer y de Ángel Galán Sánchez ${ }^{6}$.

Empero, el autor que más y mejor ha estudiado la Renta de la Seda ha sido el profesor almeriense Félix García Gámez ${ }^{7}$, autor de una serie de artículos del mayor interés que no sólo abarcan el período clásico (época mudéjar y

1 CARANDE THOVAR, 1977. ULLOA, 1977.

2 BEJARANO ROBLES, 1951.

3 GARRAD, 1956.

4 GARZÓN PAREJA, 1972.

5 LADERO QUESADA, 1988. VERA DELGADO, 1986. TORRES FERNÁNDEZ, 1995. CASTILLO FERNÁNDEZ y MUÑOZ BUENDÍA, 2000.

6 LÓPEZ DE COCA CASTAÑER, 1991; 1996. GALÁN SÁNCHEZ, 2006.

7 GARCÍA GAMEZ, 1998; 2001; 2003-2004; 2004; 2007. 
siglo XVI), sino que nos transportan de lleno al Seiscientos, mérito indiscutible de entrada pues en esa etapa tardía sólo contábamos con algunos datos proporcionados por el hispanista James Casey en sus interesantes estudios sobre la Granada moderna ${ }^{8}$.

Trabajos sobre la seda hay, por tanto. Mas en casi ninguno de ellos se aborda el aspecto social de la cuestión ${ }^{9}$. O este ni se menciona, o las interpretaciones son imprecisas e insuficientes. No por culpa, algunas veces, de los autores, a los que no ha interesado esta perspectiva, ni tenía por qué vista la metodología que fundamentaba sus estudios. Pero es un gran vacío. Y más en una época en la que las compañías comerciales tienen como es conocido una clarísima vertiente familiar, y cuando el arrendamiento de rentas fue, ya empieza a asumirse, una de las principales formas de acumulación de riqueza y, posteriormente, una eficaz plataforma para el ascenso social.

Es por ello por lo que he decidido centrar mi análisis en este terreno. Plantear de forma general y mediante el recurso de una ingente documentación de archivo, aquí citada expresamente en un ínfimo porcentaje, qué hubo, socialmente hablando, detrás del negocio de la seda granadina. Y lo que hubo, ya se anticipa, fue un entramado familiar, continuado durante cien años, y un monopolio judeoconverso, con idéntica duración. Fue el negocio del siglo, si así se me permite llamarlo.

\section{Toledanos}

La renta de la seda de Granada fue, sin duda alguna, un negocio toledano. Durante el siglo XVI, eso sí, pues después cambia radicalmente el perfil social de los arrendatarios ${ }^{10}$, dividiéndose en grupos mucho más heterogéneos y fragmentados. El Seiscientos mezclará con altibajos a los mal llamados marranos portugueses con los sempiternos genoveses, los moriscos tardíos y con grupos de mercaderes locales aparentemente cristiano viejos...

Más en la centuria anterior, todos o casi todos los arrendadores procedieron de la Ciudad Imperial. O bien eran vecinos de la misma y desde esa atalaya mercaban con el sur peninsular, o bien siendo naturales de ella, se asenta-

8 CASEY, 2008.

9 Nada particular de lo que estudiamos, pues lo mismo sucede en líneas generales con otros estudios de valor sobre la seda y todo lo que le rodea en el ámbito de otros territorios de la Corona de Castilla. Es el caso de BRUMONT, 2009. La excepción, MIRALLES MARTÍNEZ, 2002.

10 Por mera comodidad, usaré indistintamente en este artículo los términos arrendatario y arrendador con idéntico significado, el de tomador de una renta, pues así lo establece el DRAE y, además, en la documentación de la época arrendador aparece con el doble valor de dador y tomador. 
ron en tierras granadinas (Granada, Motril, Vélez Málaga...), manteniendo durante largo tiempo relaciones de todo tipo con su solar natal. Incluyendo el establecimiento durante generaciones de enlaces matrimoniales con sus parientes en la ciudad del Tajo.

Nada raro, si atendemos a la enorme importancia que tuvo la producción sedera en el Toledo bajomedieval y moderno, algo manifestado sucesivamente por los distintos historiadores que han trabajado tan relevante urbe castellana desde esta perspectiva ${ }^{11}$. La importancia de la seda toledana explica la presencia en Granada, y los beneficios y la producción granadinos justifican el sostenimiento de Toledo como centro mercantil y artesanal durante largo tiempo.

Pero los toledanos no sólo destacaron en el nivel fiscal, sino que la mayoría de los mercaderes granadinos dedicados a la seda, de forma total o parcial (se solía alternar con el tráfico de otras mercancías textiles) provinieron de Toledo. En los protocolos notariales nos aparecen centenares de nombres, y eso sólo para el siglo XVI. Pero no es mi propósito aportar listados sin mayor sentido, sino que intentaré integrarlos, en la medida de lo posible, de forma grupal. Pues no son individuos aislados los que traficaban con seda, sino que tanto actuando por libre como en forma de compañías comerciales, lo que se observa una vez que se cruzan los datos de archivo son las omnipresentes relaciones familiares.

Más que personas, pues, hablamos de extensas parentelas, emigradas desde Toledo en momentos distintos, unos inmediatamente tras la conquista de Granada, otros a lo largo de las décadas centrales del Quinientos, algunos a raíz de la repoblación derivada de la expulsión de los moriscos... En unos casos, por motivos meramente económicos; en otros, posiblemente para escapar a tierras mas amigables inquisitorialmente hablando.

Y tales parentelas se conformaron con la combinación de varias familias distintas, pertenecientes a distintos linajes que en muchos casos ya venían entrecruzándose durante generaciones, incluso desde la icónica fecha de 1391. Pues como veremos más adelante todos ellos son cristianos nuevos, conversos de judíos, conformadores de la poderosa mesocracia toledana y, por extensión, de un alto porcentaje de la élite local granadina.

Apellidos como Cepeda, Alcocer, San Pedro, Ortiz, Acre, De la Fuente, Hurtado, Velluga... se repiten como una salmodia en los documentos relacionados con el comercio de la seda. Y no sólo constan entre los registros notariales, vendiendo y comprando, prestando y dando poderes, sino que se hallan por doquier en las innúmeras dispensas matrimoniales del correspondiente fondo documental del Archivo Diocesano de Granada. Bulas pontificias que permiten la consanguinidad entrecruzada, a veces de forma brutal, que entre

11 MONTEMAYOR, 1996. RODRÍGUEZ DE GRACIA, 2002. SANTOS VAQUERO, 1998; 2009. 
los granadinos y toledanos, todos del mismo origen geográfico antes o después, se da hasta principios del siglo XVII.

La relación entre Toledo y la seda de Granada la advirtieron algunos de los principales historiadores que han analizado el tema. Desde los datos de archivo, casi todos del fondo de protocolos notariales y del archivo catedralicio, proporcionados por José Carlos Gómez-Menor Fuentes ${ }^{12}$, hasta los trabajos científicos de autores como Linda Martz, David Alonso García y Julián Montemayor $^{13}$. Pero estos estudios, de buena factura, no han hecho sino acercarse a la superficie de un fenómeno histórico de gran calado que sin duda alguna merece mayor atención.

Un buen ejemplo de estos clanes toledanos dedicados al trabajo de la seda en todas sus vertientes lo encontramos entre los Oseguera, un linaje oriundo de aquella ciudad y transplantado a comienzos del siglo XVI a la de Granada, al calor de las oportunidades surgidas tras la conquista. Aunque para ser más exactos, mejor sería hablar de una extensa parentela que de un linaje, pues parece haber muchas familias distintas compartiendo apellido pero no varonía, ya que parece que usaron esta denominación en primer lugar bastantes individuos por herencia materna.

Debieron de asentarse en el territorio meridional muy tempranamente, pues ya encontramos en 1543 a Alonso de Oseguera, beneficiado de la iglesia de la Encarnación de Lújar, pequeña aldea de la tahá alpujarreña de Órgiva, permutando su beneficio con el de la parroquia de San Nicolás de Granada, que a la sazón era propiedad de Hernando de Barragán ${ }^{14}$. Por otro lado, sabemos que Rodrigo Ponce de Ocampo, caballero veinticuatro de Granada y caballero de Santiago (1535), noble zamorano, hijo de conquistadores, se desposó con la toledana doña Juana de Vargas, asentada en Granada sobre 1515. Esta dama era hija de Pedro Gómez de Oseguera y de María de Vargas, ambos hijos de sendos jurados de Toledo ${ }^{15}$.

En Toledo los Oseguera disfrutaban desde antiguo de una destacada posición en la mesocracia local. De hecho, conformaron una de las principales dinastías de escribanos locales, con conexiones en el cabildo urbano, pues también fueron jurados y fieles ejecutores ${ }^{16}$. Todo ello, entre finales del siglo

12 GÓMEZ-MENOR FUENTES, 1970a; 1970b.

13 MARTZ, 2001. ALONSO GARCÍA, 2005. MONTEMAYOR, 1996.

14 AGS, Cámara de Castilla, legajo 269, exp. 49. De la figura de este beneficiado, nos da algunas noticias GARCÍA PEDRAZA, 2002: 324.

15 AHN, Órdenes, Santiago, exp. 4010 (Juan Hurtado de Ocampo y Oseguera, 1568).

16 AGS, Registro General del Sello, 17 de noviembre de 1502, título de fiel ejecutor del estado de los ciudadanos de Toledo a Diego Hernández de Oseguera por renuncia de Juan Hernández de Oseguera, su tío. Este Juan Hernández de Oseguera ostentaba ese cargo desde 1484 por resignación de Ruy Sánchez Cota, miembro de la célebre estirpe confesa de su apellido, AHN, Órdenes, Santiago, exp. 4010, 8 de julio de 1484. 
XV y comienzos del XVI, época en la que más brillaron, tal y como nos indica Palencia Herrejón, para quien:

Los Oseguera constituyen una dinastía muy particular de escribanos, representan la familia de hombres de letras que alcanzó una destacada posición social y un alto grado de influencia en los ámbitos de decisión institucionales de Toledo hacia 1500 , en particular en el Colegio de Escribanos y en la propia ciudad ${ }^{17}$.

Escribanos, sí, pero en absoluto ajenos al universo mercantil, pues sabemos que efectuaron inversiones y transacciones del mayor interés, ambiente en el que podemos insertar a la perfección a los hombres y mujeres que desde Toledo emigraron a la ciudad de Granada, en búsqueda sin duda de oportunidades económicas. Sin poder enlazarlos a todos en un único esquema genealógico, debido a la enorme complejidad que muestra este grupo (señal más que probable de ser, aunque parientes, miembros de distintas familias), bastará para demostrar la relación secular de los Oseguera con la seda de Granada una breve relación de personas y circunstancias.

Así, personajes de relieve en la vida local de la Granada del Siglo de Oro como Francisco de Oseguera, que aparece como mercader en torno a 158818; Gaspar de Cuadros y Oseguera, mercader a fines del Quinientos ${ }^{19}$; Alonso de Oseguera Hinojosa, que a la vez fue escribano de Su Majestad y jeliz de la seda, nacido alrededor de $1576^{20}$; o Bartolomé de Oseguera, jeliz en la Alcaicería en $1657^{21}$, y don Luis de Oseguera, mercader y yerno de mercaderes de seda a mediados del Seiscientos ${ }^{22}$.

Pero no únicamente constan estos cinco varones, sino que muchas de las mujeres de la parentela casaron con mercaderes de seda. Relaciones, eso sí, que muchas veces se hurtan al investigador en los documentos más «oficiales», quedando registrados en los prosaicos registros notariales. Sucedió así con doña María de Oseguera, quien al testificar en 1622 a sus avanzados 85 años de edad, en el proceso de beatificación de San Juan de Dios, declaró ser viuda de Francisco Fernández de Aranda, sin añadir ocupación alguna a su difunto esposo. Si cruzamos los datos, encontraremos que éste no fue sino mercader de sedas, como se proclama en varios documentos entre 1580 y $1608^{23}$.

17 PALENCIA HERREJÓN, 1999: 817.

18 APG, G273, fol. 141.

19 Dote de Gaspar de Cuadros y doña María de Padilla, APG, G305, fol. 2570.

20 En 1626 testifica en un pleito sobre la escribanía de la Renta de la Seda, indicando tener más de 50 años y ser vecino de la parroquia de la Magdalena, ARChG, legajo 2411, pieza 11.

21 APG, G765, fol. 191.

22 APG, G724, fol. 186. El testamento se otorgó el 16 de agosto de 1651.

23 ADG, libro 7799, fol. 143; APG, G230, fol. 443; AGI, Contratación, legajo 5308, exp. 2, fol. 19. Como mercader y jurado se presenta en AHN, Inquisición, legajo 1441, exp. 9 (vecino a San Cecilio, contaba con 54 años de edad en 1654). 
Lo mismo sucede con doña Clara de Oseguera, mujer de Alonso de la Paz Candelero, jurado de Granada y mercader de sedas, que como ya he dicho aparece con una u otra profesión, o ninguna, según el tipo de documento. Sin nada más que su nombre, en una escritura relacionada con la sobrina de su esposa, mujer del alguacil mayor perpetuo de la villa de Moclín, el capitán don Pedro Ruiz de Prado Mesía, cabeza de una ilustre familia de la hidalguía local. Como jurado, claro está, en los documentos administrativos, en este caso simanquinos. Como mercader de sedas, en una fianza ante escribano ${ }^{24}$.

Pero también se da la circunstancia inversa, que miembros del linaje Oseguera, sin aparente relación con el mundo de la seda, estén enlazados matrimonialmente con grupos familiares dedicados a la comercialización de tan productiva materia. Una vez más, el recurso al cruzamiento sistemático de fuentes se torna indispensable para averiguar la verdad que se esconde tras las apariencias documentales.

Un buen ejemplo de ello nos lo proporciona el ya mencionado Alonso de Oseguera Hinojosa, que en bastantes ocasiones emerge de los legajos sólo con el prestigioso cargo de familiar del Santo Oficio. Si no dispusiéramos del documento antes citado, podríamos inferir su condición de sedero al analizar la parentela de su esposa, doña Luisa Jiménez de la Cerda, miembro del mismo grupo que dio a Juan Jiménez de la Cerda, mercader de seda y vecino de la parroquia de la Magdalena en 1672, fecha en la que cuenta con 54 años; de Luis Jiménez de la Cerda, mercader de sedas en 1646; y de Bernardo, de los mismos apellidos, que lo es también por $1655^{25}$.

El evidente éxito en los negocios acabó, como sucedía casi siempre, por proyectarlos a la esfera local del poder. Comenzando por los oficios de jurado, perfectos para un grupo familiar dedicado de lleno a lo mercantil. Este fue el caso de Pedro Díaz de Oseguera, mercader y sedas y jurado de Granada al que hallamos renunciando su cargo en manos de Andrés de la Torre en $1663^{26}$. Dos hijos de este Pedro y de doña Francisca de Aguirre fueron caballeros veinticuatros del cabildo urbano: don Manuel, que pagó 60.000 reales por el oficio en 1667 a su anterior propietario, don Juan de Figueredo; y don Alonso de Oseguera y Aguirre, éste sucesor de su hermano en $1672^{27}$, esposo de doña Mariana Gallardo de la Daga, miembro de otro linaje de hombres

24 Respectivamente, APG, Moclín, 1649-52, escribano Esteban Díaz Ramos, fol. 148; AGS, Cámara de Castilla, leg. 2451; APG, G618, fol. 791.

25 APG, G610, fol. 563, en que consta su condición de familiar de la Inquisición y el nombre de su esposa; los tres parientes citados, en AHN, Inquisición, legajo 1528, exp. 9; APG, G705, fol. 685; y APG, G750, fol. 365.

26 AGS, Cámara de Castilla, títulos rasgados, legajo 132, s.f.

27 El primer dato, de AGS, Cámara de Castilla, legajo 2420, s.f. (hechas de renuncias). El segundo, en MORENO GARZÓN, JIMÉNEZ ALARCÓN y PARRA ARCAS, 1986: 69. 
nuevos encaramados gracias a su riqueza al regimiento desde la esfera comercial y el puesto previo de jurado 28 .

He destacado los Oseguera, pese a lo que pudiera parecer, no por sobresalientes, sino precisamente por discretos. Se trata de un grupo de parentesco no especialmente complejo ni relevante, si lo comparamos con otros muchos de los que manejo información. De ahí su interés, al ser más la norma de un conjunto de familias que la excepción.

Cuánto se podría hablar de estos mercaderes. Por ejemplo, de Juan Álvarez Dávila, que llegó a ser jurado de Granada, hijo de Baltasar Francés, vecino de Toledo. Se trata de uno de los más activos mercaderes de seda, del que se dice que desde muy joven manejó la hacienda y caudal de su padre «y tuvo a su cargo su escritorio y sedas y mercaderías $\rangle^{29}$. O de toledanos recién asentados como Diego de San Pedro, que en 1532 paga a sendos paisanos, pero establecidos los tres desde hacía poco en Granada, 186.417 maravedís procedentes de la seda en madejas que le dieron. Y estos acreedores suyos eran el escribano público Juan de Alcocer y el mercader Rodrigo de Alcocer, ambos miembros de la extensísima estirpe de su apellido ${ }^{30}$.

Y como los anteriores, otro Alcocer, Alonso de nombre de pila, mercader que registra su seda para pagar la alcabala a los arrendadores de la renta en 1561. Curioso documento, pues el arrendatario del impuesto era el señor Juan de Alcocer y el escribano ante quien se escritura, Melchor de Alcocer. Todos tres lejanos parientes, y de una forma u otra, como los de una generación antes, implicados de lleno en el negocio ${ }^{31}$.

De parecida forma, los San Pedro. Para muestra, un botón, encarnado en un par de documentos ante el citado notario Melchor de Alcocer, esta vez del año anterior, 1560. Entre los nombres que desfilan por los folios del protocolo hallamos al mercader Gonzalo de San Pedro, vecino a la parroquia de la Iglesia Mayor, y al huérfano, aún menor de edad, Juan de San Pedro, hilador de seda, hijo de un escribano de Su Majestad. Una muestra más de las complejas relaciones profesionales, familiares y sociales que se entretejían en torno a este producto $^{32}$.

28 La condición de jurado de Mateo Gallardo de la Daga, suegro del regidor Oseguera, entre otros muchos documentos, en ARChG, legajo 14441, pieza 25. De él se dice en Íbid, legajo 652, pieza 17, que «es de las personas más acomodadas que tiene Granada y tiene reputación su hacienda de doscientos mil ducados». La sucesión del oficio de veinticuatro en sus descendientes, en MORENO GARZÓN, JIMÉNEZ ALARCÓN y PARRA ARCAS, 1986: 66.

29 APG, G283, fol. 38.

30 APG, G35, fol. 116v.

31 APG, G123, fol. 17.

32 APG, G115, fols. 17 y $25 \mathrm{v}$.

Hispania, 2016, vol. LXXVI, nº. 253, mayo-agosto, págs. 415-444, ISSN: 0018-2141, e-ISSN: 1988-8368, doi: 10.3989/hispania.2016.013 
Podríamos seguir así ad nauseam, y no va a ser el caso. Pero sí que quiero traer a colación algunas dispensas matrimoniales para mostrar el fenómeno antes enunciado de la consanguinidad entablada durante un siglo entre los distintos grupos de origen toledano, asentados directa o indirectamente en el territorio meridional. Y para mostrar cómo no se van perdiendo los lazos de solidaridad interna del colectivo hasta muy adelante en el tiempo, me centraré en un único expediente, uno entre muchas decenas.

En 1575 Francisco de la Torre demandaba ante el provisor eclesiástico poderse casar con su prima Ana Velluga, a pesar de los lazos de parentesco que les unían. El joven, nacido en Granada, era hijo de María de San Pedro y de Juan de la Torre Velluga, hijo a su vez de Francisco de la Torre, de cuyo hermano Hernando de la Torre era nieta la contrayente, hija de su hijo Juan Velluga y de Catalina de la Fuente ${ }^{33}$.

Una vez más, y no será la última, que protagonizan estas paginas los Torre, De la Fuente, Velluga (Velluga Moncada)... Siempre, ligados a la seda. Como en esta misma ocasión, en la que el excepcionalmente rico documento nos añade a lo anterior información económica del mayor interés. Según los testigos, la calidad de la novia requería una dote competente de dos o tres mil ducados, cuestión problemática ya que el padre no tenía de hacienda más de 3.500 ducados, y siendo siete hermanos con ella, sus perspectivas hereditarias eran de unos 500, o quizá 600 como mucho, ya que dos de estos habían renunciado a sus legítimas al entrar en la Compañía de Jesús.

Pero la mayor trascendencia de este expediente, a mi entender, proviene de los datos que nos muestran una vez más cómo se casan entre parientes dentro del ámbito sedero. El joven casadero, de 24 años, tiene por oficio el escribir en la aduana en los libros de la seda. El padre de la novia, por su parte, tiene a su cargo el libro de la seda, en la misma aduana sita en la Alcaicería granadina, donde consta «lo que se despacha por los jelizes de ella de la seda que se trae a vender».

\section{UNA GRAN FAMILIA}

Vistos algunos ejemplos de los múltiples lazos de consanguinidad que unían al grupo, una ínfima muestra del total, estoy en condiciones de afirmar que casi todos los participantes en el gran juego de la seda de Granada eran parientes entre sí de una u otra forma. Se trata de una gran familia, con cientos de ramificaciones, de líneas que se entrecruzan, que tienen su sede en Toledo y Granada, pero que también cuentan con nodos de menor trascendencia

\footnotetext{
33 ACuG, expedientes matrimoniales, microfilm 1453489, exp. 176.
} 
en poblaciones como Málaga, Vélez Málaga o Guadix, entre otras, y fuera del reino, en Sevilla, Murcia...

Y este parentesco se encuentra especialmente entre los grandes personajes que protagonizaron este proceso, los arrendadores de la renta de la seda. Todos ellos, como veremos de inmediato, estaban estrechamente emparentados, dato por completo desconocido hasta el momento. Circunstancia, por ende, del mayor interés, pues convierte a este productivo negocio en una colosal empresa familiar que duró unos cien años, hasta su extinción por muy diversas causas.

Entre los primeros grandes arrendadores de la seda sobresalen Juan de la Fuente y Hernando Hurtado (1505-1507, ambos, y 1508-1510 el primero ${ }^{34}$ ); ambos fueron cuñados ${ }^{35}$. Y Juan, hermano de Diego de la Fuente, compartiendo ambos hermanos la administración de la renta entre 1511 y 1516 . De Juan fue hija Teresa, mujer de Día Sánchez Dávila, que tuvo la renta como veremos entre 1553 y 1560. Pero son los hijos de Diego de la Fuente los que más arrendadores conectan entre sí.

Uno de sus hijos fue Rodrigo Hurtado de la Fuente, padre de los hermanos Hurtado de la Fuente, toledanos de Puebla de Montalbán asentados en Motril, arrendadores de la renta entre 1584 y $1591^{36}$. La otra, Teresa de la Fuente, segunda esposa del arrendador de la seda granadina (1517-1524 y 1525-1546) Juan de la Torre, regidor de Toledo y de Granada y señor de la villa de Vélez de Benaudalla. Este, de su primera esposa Leonor Ortiz, otra toledana, tuvo a Alonso de la Torre, veinticuatro de Granada e igualmente arrendatario del impuesto (1561-1563).

Más aún, el compañero de Juan de la Torre en el arrendamiento del período 1517-1524 fue Alonso de Toledo, su propio cuñado, como marido de su hermana Leonor de la Torre. Prima hermana de ambos fue Mencía de la Torre, mujer de Hernando de Alcocer, abuelos paternos de tres sucesivos arrendadores de la renta de la seda, a saber Juan de Alcocer (1547-1552 y 15611563), Hernando Díaz de Alcocer (1569-1573 y 1573-1581) y Antonio Álvarez de Alcocer (1569-1573) 37 .

La figura de otro de los arrendadores de la seda, Día Sánchez Dávila, a pesar de la enorme trascendencia que tuvo en su momento, ha quedado casi por completo oscurecida por el paso del tiempo. Ciertamente, Sánchez Dávila no provenía de Toledo, pero tuvo una fuerte relación con la Ciudad Imperial,

34 Los períodos de administración de la renta de la seda los proporcionan varios autores; escojo para la ocasión el cuadro actualizado que publicó MARTZ, 2001: 160.

35 ALONSO GARCÍA, 2005: 18.

36 Aunque la misma aparezca habitualmente a nombre de Álvaro López, como se ve en el cuadro que proporciona GARCÍA GÁMEZ, 1998: 268.

37 Todos estos datos genealógicos y prosopograficos proceden de SORIA MESA, 2014b. 
establecida mediante negocios comunes con los mercaderes de esta vecindad, y afianzada con su ya citado casamiento con doña Teresa de la Fuente. Tras ardua investigación, he podido establecer el abolengo de esta señora, hija de Juan de la Fuente y de Catalina de Torre, y hermana de Rodrigo de la Fuente, que casó con una Lebrija, de la familia del gran Antonio de Nebrija, asentada en Granada ${ }^{38}$.

Estos entronques se convierten de inmediato en conexiones con la seda y Toledo. Juan de la Fuente, padre de doña Teresa, es nada menos que el arrendador de la seda en los primeros tiempos tras la conquista, junto con su hermano Diego de la Fuente. Y, como ya se ha visto, de este Diego nació otra doña Teresa de la Fuente, mujer de Juan de la Torre, también tomador del impuesto y señor de Vélez de Benaudalla. Recapitulando, Día Sánchez Dávila era yerno de un arrendador de la seda, y sobrino y primo hermano político de otros tantos.

La actividad de nuestro personaje fue febril, aunque por desgracia sólo conocemos fragmentos de su trayectoria personal, económica y política, pues no nos ha llegado su archivo, o si éste se conserva, no está disponible para el investigador ${ }^{39}$. En cualquier caso, por los retazos que dejan constancia los protocolos notariales, las fuentes judiciales y los documentos administrativos de todo tipo sabemos que primero fue jurado de Granada, oficio del que consiguió la merced regia en $1520^{40}$. Posteriormente, llegó a ser veinticuatro de Granada, regidor de Jaén y señor de vasallos ${ }^{41}$.

La adquisición en 1549 del señorío de Cázulas, pequeño enclave cercano a la costa granadina, recuerda a la posesión de la villa de Vélez de Benaudalla por Juan de la Torre. Inversión económica, valiosa propiedad que puede ser hipotecada y usarse como aval financiero y elemento de ascenso social que convirtió a ambos hombres de negocios de notoria progenie hebraica en señores de vasallos ${ }^{42}$.

Una demostración evidente de que nos movemos en estrechos círculos de parentesco, ocultado por la documentación oficial, la tenemos en el caso de los fiadores de algunos de estos arrendatarios de la seda granadina. Seguro pariente de Día Sánchez Dávila fue el jurado granadino Hernando del Campo, el cual aparece junto con su mujer Beatriz de Rueda como avalista suyo. Pero también fue, años después, fiador de Juan de Alcocer y de Alonso de la Torre en el mismo negocio de la seda.

38 SORIA MESA, 2014 b.

39 Tiene poco valor en este sentido, pues casi no incluye documentos suyos, el libro de MALPICA CUELLO, QUESADA QUESADA y RUEDA LLORCA, 1982.

40 Renuncia del oficio por Francisco de Peñalver, AGS, Registro General del Sello, 10 de abril de 1520 .

41 Sobre el regimiento de Jaén (c. 1547), APG, G66, fol. 304v. Consta como caballero veinticuatro en APG, G96, fol. 261v.

42 Las vicisitudes del señorío de Cázulas, en SORIA MESA, 1997a: 271. 
El parentesco procede de su mujer, Beatriz de Rueda, precisamente el mismo nombre de la madre de Dávila, que unos documentos llaman Beatriz González y otros Beatriz González de Rueda. Más aún, aunque el jurado Hernando del Campo parece tener un origen murciano, según consta en la probanza de hidalguía de su familia ${ }^{43}$ (si es que no encubre falsedades), existe una clara vinculación con Toledo por parte suya y de su sobrino carnal y socio Bartolomé del Campo. Por un lado, porque hermano de Beatriz de Rueda fue un tal Antonio de Rueda, vecino de la Ciudad Imperial a la altura de 1560. $\mathrm{Y}$ a éste le dio poder Hernando del Campo para que en su nombre se obligara con el cabildo de la catedral primada hasta en 2.000 ducados $^{44}$, señal clara de su interés económico por la zona.

Por otra parte, porque el citado Bartolomé del Campo casó con la toledana Catalina de Torres Píñar, miembro de una interesante familia judeoconversa que procedente de Toledo se asentó pronto en el reino de Granada, tanto en la capital como en otras zonas, dedicándose entre otras cosas al arrendamiento de rentas. Hermano de Catalina fue Bernardino, administrador general de los solimanes y azogues entre los años 1584 y $1592^{45}$. Este matrimonio debió celebrarse a mediados del siglo XVI, pues una de las hijas de ambos casaba en 1585 con un pariente cercano, reanudando los lazos que unían a la parentela ${ }^{46}$.

\section{UN NEGOCIO JUDEOCONVERSO}

Bastantes de los autores que me han precedido en el estudio de la cuestión han advertido que al menos parte de los arrendadores de la seda fueron de condición conversa. Linda Martz, desde luego, fue muy consciente de ello debido a que se encontraba con los mismos nombres y apellidos, y a veces con idénticos personajes, con los que se topó en sus estudios sobre los judeoconversos toledanos ${ }^{47}$.

Pero no se trata, en mi opinión, de que haya más o menos conversos en torno a este negocio. Sino de que el negocio de la seda, producción, comercialización y administración de la renta fue un entramado absolutamente dominado por los confesos. Por descendientes de judíos, cristianos desde hacía unas generaciones, que invirtieron dinero, tiempo y esfuerzos para controlar por completo durante un siglo este sector productivo.

Lo que sucede es que en Granada, como ya he dicho en alguna ocasión, lo morisco ha ocultado a lo judeoconverso. La transcendencia innegable de lo

43 ARChG, legajo 2872, pieza 1.

44 APG, G115, f. 422.

45 APG, G246, f. 367 y G296, f. 937.

46 ACuG, expedientes matrimoniales, microfilm 1453490, exp. 92.

47 MARTZ, 2001; 2003. 
islámico ha hecho que quede en un plano secundario, cuando no olvidada por completo, la realidad conversa. Un fenómeno que fue el auténtico protagonista de la evolución de la nobleza y élites locales, y que sin embargo es una de las principales lagunas de la historiografía granadina.

Las razones que explican la presencia masiva de cristianos nuevos de origen hebraico en Granada son varias, y bien sencillas. Por un lado, se trata de un territorio recién conquistado e incorporado a la Corona, en donde todos los inmigrantes carecen de pasado. Las posibilidades de empezar de cero, o casi de cero, son enormes y muy atractivas para aquellos que tienen mucho que ocultar. Cualquiera puede, tras enriquecerse, trocar un abuelo judaizante por un conquistador montañés.

Más importante aún es el hecho de que hasta 1526 no existiera tribunal de la Inquisición en el reino. A excepción del paréntesis de Lucero, que realizó ciertas razzias desde la sede del Santo Oficio de Córdoba, durante más de tres décadas no hubo que preocuparse mucho en este sentido, y ese fue un excelente motivo para arraigarse en las comarcas granadinas.

Además, cuando se active el tribunal y comience su persecución de la heterodoxia, su preocupación fundamental serán los criptoislámicos, no los conversos de judío, que no plantean más problemas que la desviación individual del dogma, y que hasta 1593 no causarán inquietud real alguna.

Por último, Granada era una tierra de oportunidades económicas como pocas. Muchos productos de exportación (seda, lana, azúcar, pasa...), unos moriscos fácilmente explotables y unas rentas tan complejas que requerían especialistas del mayor nivel componían un fresco irresistible. En este último sentido, y como escribí hace años,

\begin{abstract}
la confusa administración de las rentas de origen nazarí, así como de las nuevas introducidas por los castellanos, permite demostrar su secular habilidad a auténticos linajes de profesionales de la hacienda pública: serán decenas o cientos los recaudadores, receptores, contadores, mayordomos, tesoreros... que aprovechen la intrincadísima red impositiva ${ }^{48}$.
\end{abstract}

En este sentido, la propia complejidad de la gestión de la Renta de la Seda explica en buena medida el monopolio que en la práctica consiguieron los judeoconversos, ya que se necesitaba de un capital humano muy especializado, y en la práctica sólo ellos disponían de él, gracias al control previo de las grandes rutas comerciales y al arrendamiento de impuestos.

Los datos de archivo, centrados de forma concreta en una u otra familia conversa, nos proporcionan una mera muestra de lo expuesto, ya que la gran mayoría de los papeles de la Inquisición se han perdido, entre ellos casi todos

\footnotetext{
48 SORIA MESA, 1999: 106.
} 
los del tribunal granadino. De cualquier forma, son suficientes para darnos una idea de la enorme trascendencia que tuvieron los conversos en el sector sedero local. Así, en genealogías toledanas presentadas ante el tribunal de esa urbe se nos menciona al confeso Juan de Rojas, natural de la Puebla de Montalbán, asentado a comienzos del siglo XVI en Granada y muerto en esa ciudad, quien «entendía en cosas de seda ${ }^{49}$. Sin duda, un miembro de la parentela del autor de la Celestina.

$\mathrm{Y}$ en parecidos listados constan en el siglo XVI, aunque sin poder precisar más sus circunstancias, los granadinos Miguel Fernández, guarda de la seda, penitenciado; Alonso Fernández, mercader de sedas, que debió dar su genealogía al Santo Oficio como descendiente de condenados ${ }^{50}$; Francisco Álvarez de Montalvo torcedor de seda, y Rodrigo Gómez, hilador del mismo material, ambos procesados por la Inquisición pero finalmente absueltos ${ }^{51}$. Todos ellos, claro está, por sospecha de ser judaizantes.

Y sin deseo de prolongarnos eternamente refiriendo casos, cerremos este apartado introductorio con la figura de doña Aldonza de Rojas, una de las tantas mujeres de la mesocracia granadina de origen judeoconverso que fue procesada por la Inquisición a finales del Quinientos y que salió en uno de los autos de fe que se desarrollaron entre 1593 y 1595 en la ciudad del Darro por seguir la ley mosaica ${ }^{52}$. Concretamente, en el de 27 de mayo de 1593.

Esta señora, miembro de un clan converso que controlaba la Real Chancillería $^{53}$ (los Santofimia), era hija del toledano Gonzalo de San Pedro, mercader de sedas, y esposa de Alonso de la Torre, de idéntica dedicación laboral ${ }^{54}$. En este caso se trata de un grupo que proviene de Toledo, dedicado a la seda, y que desemboca en una extensa parentela, casi toda ella procedente de Écija, volcada en el ámbito burocrático.

Por su parte, dentro de la primera gran compañía dedicada al arrendamiento de rentas (y entre ellas, las provenientes de la seda) en el reino meridional, formada por Alonso de Toledo y Alonso de Alanís (1497-1500), encontramos un tercer personaje, Juan de Córdoba, hijo de Benito Sánchez Leví. El hallazgo de otra genealogía dada ante el Santo Oficio por judeoconversos descendientes de condenados, esta vez de manos de Benito Sánchez Leví, sobrino carnal y homónimo del que acabo de mencionar, nos proporciona valiosísimos datos sobre este personaje, capaces de situarlo socialmente con bastante precisión ${ }^{55}$.

49 AHN, Inquisición, legajo 287, exp. 13.

50 Ambos casos en AHN, Inquisición, legajo 1501, exp. 1.

51 AHN, Inquisición, 1539, exp. 10.

52 GARCÍA IVARS, 1991.

53 SORIA MESA, 2005.

54 Datos que conocemos al detallar ella su propia genealogía ante el Santo Oficio, AHN, Inquisición, legajo 5237, exp. 15, fols. 148 y ss.

55 AHN, Inquisición, legajo 1492, exp. 1. 
De esta forma, Benito, el padre del arrendador Juan de Córdoba Leví, se sitúa dentro de un grupo de parentesco basado tiempo atrás en el comercio y el arrendamiento de rentas. Si su hijo tuvo la compañía citada, él mismo fue obligado a las carnicerías de Baena y Granada, administró los estancos de la carne y cera en esta ciudad, y fue en 1502 arrendador de los diezmos de la capital granadina ${ }^{56}$. Su padre Juan Sánchez Leví fue mercader, y sus pasos los siguieron sus otros hijos, hermanos de nuestro personaje, avecindados todos ellos en Córdoba. Así, Pedro fue tratante en mulas; Leonor casó con Rodrigo de Palma, mercader; y Alonso Sánchez Leví fue tratante y vinatero, mientras que de los hijos de éste, Benito, el de la testificación genealógica que seguimos, fue mercader, mientras que Constanza casó con el mercader Diego López de Marruecos.

Y muchos de ellos sufrieron encontronazos con la Inquisición. Benito fue reconciliado, lo mismo que su padre y sus hermanos Pedro, Leonor y Alonso. Así mismo lo fue la mujer de éste y varios hermanos de ella. En este contexto, resulta inevitable mencionar la noticia de que su sobrino Benito, por quien sabemos todo esto, huyó a Portugal junto con su mujer, escapando de la brutal represión sufrida en Córdoba por parte del inquisidor Lucero.

Añadamos a esto el enlace ya mencionado con Diego López de Marruecos, miembro de una de las principales familias de cristianos nuevos del reino de Jaén, cuyos miembros padecieron gravemente los zarpazos de los primeros momentos de la Inquisición ${ }^{57}$. Y el enlace de Alonso Sánchez Leví, hermano del arrendador Benito, con Leonor Rodríguez, hermana del licenciado Gonzalo Rodríguez de Santa Cruz, médico, que nos transporta a una importante estirpe cordobesa de profesionales de la medicina, los cuales no sólo fueron de origen judío como no podía ser de otra forma, sino que experimentaron también la represión religiosa del tribunal de la fe ${ }^{58}$.

Siguiendo con los primeros momentos del desarrollo de esta renta particular, encontramos a otro toledano, Alonso Pérez de la Fuente, arrendador de la seda entre 1501 y 1504 . Desafortunadamente, no lo he podido filiar con exactitud, y hay tantos homónimos y personas que usan en Toledo y Granada del apellido Pérez de la Fuente, que no logro hilvanar un contexto familiar correcto. Del personaje han tratado los especialistas, no sólo a nivel local sino también en el concierto de rentas de casi toda Castilla, donde tan activo fue por estos años ${ }^{59}$.

56 La primera información, de la declaración del sobrino; la segunda, en MORENO TRUJILLO. 2010: 200; la tercera, de AGS, Registro General del Sello, 15/X/1502.

57 Interesa al respecto CORONAS TEJADA, 1988.

58 CABRERA SÁNCHEZ, 2002.

59 Por ejemplo, lo mencionan CARRETERO ZAMORA y ALONSO GARCÍA, 2003: 18 , entre otras. 
$\mathrm{Su}$ condición conversa no parece discutible, considerando su origen, su apellido y las redes y conexiones en su torno establecidas. Apoya el aserto la existencia, entre Granada y Toledo, de Pérez de la Fuente de progenie hebraica, relacionados igualmente con la administración de rentas reales; seguramente fueron sus cercanos parientes. Entre ellos, mencionaré tan sólo, por lo que aquí interesa, a Fernán Pérez de la Fuente, vecino de Sevilla y en ella receptor de sus rentas, quien tuvo bastante sucesión de su mujer, como él de origen toledano, doña María de Rivadeneira. Y sobrina de Fernán fue Ana de Montemayor, casada en 1550 nada menos que con Alonso de Alcocer, hijo de Rodrigo Díaz de Alcocer y de María González de la Torre. Casan, por si fuera poco, por poderes, y el apoderado es nada menos que Hernán Pérez Jarada, sevillano oriundo de la Ciudad Imperial, descendiente de condenados y centro de un nodo genealógico del mayor interés que por razones de espacio no puedo ahora desarrollar.

Pero no fue esta la única conexión directa con el entramado central de la gestión de la renta de la seda. Hija del mismo Fernán y de su citada esposa fue doña Mayor de Rivadeneira, quien casó en 1560 con Juan de la Torre, vecino de Granada, hijo de Juan de la Torre, jurado de Toledo, y de doña Francisca de la Fuente. O sea, los que fueron arrendadores de tan lucrativo impuesto ${ }^{60}$.

Sin salirnos de estos tiempos iniciales de la Granada cristiana, no conviene olvidar a Alonso de Alanís, mencionado poco antes, cabeza de una de las grandes compañías sederas, como corresponde a un gran mercader sevillano. Alanís, que fue arrendador mayor de la seda entre 1497 y 1500, fue un judeoconverso tan notorio que incluso su propia esposa, Leonor Fernández Cemendar, fue reconciliada ${ }^{61}$

Seguro pariente de Alonso, acaso su hermano, fue Juan de Alanís, solicitador general de los servicios moriscos del reino de Granada ${ }^{62}$ y jurado de Almería. Su condición conversa es tan conocida que consta claramente en documentación de la época, concretamente en la correspondencia del conde de Tendilla $^{63}$. De él y de su esposa Beatriz de Toledo fue nieta doña Ana de la Torre, mujer de Álvaro de Paz del Río, lo que una vez más nos lleva de lleno a la élite granadina ${ }^{64}$. Proceso de ennoblecimiento iniciado un poco antes con la figura del licenciado Juan de Alanís, hijo de Juan y de Beatriz, abogado de la Real Chancillería de Granada (1561) y corregidor de Carmona (1567) ${ }^{65}$.

60 Todo esto, en AGS, Expedientes de Hacienda, legajo 722, exp. 1; APG, G71, fol 337; PÉREZ DE HERRASTI, 2007: 170; GIL, 2003, IV: 271-273.

61 GIL, 2002, III: 186.

62 AGS, Cámara de Castilla, legajo 2172, oficio merced de los Reyes Católicos, que a su muerte pasó a Francisco Verdugo.

63 MORENO TRUJILLO, 2010.

64 APG, G589, fol. 959.

65 APG, G119, fol. 691 y AGS, Consejo Real, legajo 711, exp. 1. 
Y sobrino de Alonso de Alanís, esto sí está documentado, fue Rodrigo de Alanís, vecino de Málaga, criado del poderosísimo hombre de negocios converso Fernando de Córdoba. Rodrigo fue fiel del jeliz de la seda de Málaga sobre 1502, y ya en 1497 había sido nombrado receptor de la Renta de la Seda por su tío, el arrendador Alonso ${ }^{66}$.

Converso sin discusión fue otro de los arrendadores y recaudadores mayores, que así aparece, de la renta que estudiamos en los primeros tiempos. Concretamente en 1503 y 1504 encontramos a Diego Méndez de Tablada, escribano público de Granada ${ }^{67}$, receptor real, contador del Arzobispo, contino de la Casa Real... Numerosos empleos que compartió parcialmente con su hermano Sancho Méndez, jurado de la ciudad de Granada y receptor de las Alpujarras.

Este dato, que es conocido pero no ha sido interpretado anteriormente, es el que nos lleva directamente al seno de una de las principales parentelas de origen hebreo de Granada, integrada desde el primer momento entre lo más granado del patriciado local y que acabó pronto por convertirse en nobleza de sangre, incluso alcanzando algunas de sus ramas la condición aristocrática de rango nacional. Son los Salazar, divididos en varias líneas: los Méndez de Salazar, derivados de este Sancho; los Muñoz de Salazar, alféreces mayores de la ciudad de Santa Fe; y la más conocida familia de Juan Vázquez de Salazar, secretario de Felipe II, sobrino del también secretario Juan Vázquez de Molina, que a su vez lo fue del todopoderoso Francisco de los Cobos. Pese a su condición conversa, Juan Vázquez de Salazar, fue alférez mayor de Úbeda, en sucesión a su tío, señor de la villa del Mármol, por compra, y gracias a la influencia cortesana esposo nada menos que de doña María de Mendoza, hermana del octavo conde de Priego ${ }^{68}$.

Y no sólo sus conexiones con el universo converso son familiares, sino que sus estrechas relaciones con los De la Puebla, de idéntico origen, nos llevan directamente a unos parientes de éstos, los confesos Suárez de Toledo, con el tiempo vizcondes de Rías (y progenitores del gran filósofo Francisco Suárez), en esta etapa dedicados con ahínco a la gestión de rentas ${ }^{69}$.

Lo mismo podemos decir del granadino Lope de Soria, arrendador de la Renta de la Seda junto con Hernando Díaz de Alcocer para el período que transcurre entre 1573 y 1581 . Hasta ahora, nada se conocía de él. Gracias a una escritura notarial sabemos de la existencia de un Diego de Soria, vecino

${ }^{66}$ LÓPEZ BELTRÁN, 2012.

67 Oficio que renuncia ese mismo año en Francisco del Castillo, AGS, Registro General del Sello, 30/III/1504.

68 SORIA MESA, 2007.

69 GARCÍA PEDRAZA, 2010. 
de Granada a comienzos del siglo XVI ${ }^{70}$. De él fue hijo Lope de Soria, abuelo paterno de nuestro homónimo personaje. Este primer Lope fue un conocido cristiano nuevo, así se hace constar en varios documentos inquisitoriales ${ }^{71}$. Fue padre de varios hijos, cuyas respectivas descendencias generaron una fuerte endogamia al casar reiteradamente entre sí.

Uno de estos hijos fue Diego de Soria, pagador de la Real Chancillería, nacido en torno al año $1500^{72}$, personaje muy activo en la Granada de mediados del Quinientos, el mismo que debió acumular una gran fortuna gracias a su oficio y a sus inversiones y préstamos. En 1584 testaba, evidenciándose su nivel patrimonial en el cuadro siguiente:

CUADRO 1. Dotes y capitales de los hijos de Diego de Soria

\begin{tabular}{|l|l|r|l|}
\hline Nombre & \multicolumn{1}{|c|}{ Cónyuge } & $\begin{array}{c}\text { Cantidad } \\
(\mathrm{ms} .)\end{array}$ & \multicolumn{1}{c|}{ Notas } \\
\hline Lope & Leonor de Camargo & 500.000 & \\
\hline Ana & Lázaro del Adarve & 1.030 .000 & $\begin{array}{l}\text { Familia conversa, instalada en } \\
\text { la Chancillería }\end{array}$ \\
\hline María & Luis Pérez de Gadea & 950.000 & Familia de regidores de Ronda ${ }^{73}$ \\
\hline Catalina & García de Briones & 1.030 .000 & Fue jurado de Granada ${ }^{74}$ \\
\hline Luis & - & 128.582 & Fue jesuita \\
\hline Jerónimo & Isabel de Aguilera & 268.639 & Nacida en Ronda \\
\hline Jerónima & - & Casas & Demente \\
\hline
\end{tabular}

Fuente: APG, G250, fol. 974. Elaboración propia

Con un patrimonio que superaba los cuatro millones de maravedís, una auténtica fortuna en la Granada de su tiempo, no es de extrañar que su hijo mayor, Lope de Soria, arrendara la renta de la seda, como hemos visto. Pero no fue esta su única actividad en relación al ámbito financiero, pues siguiendo

70 La filiación de este primer Diego de Soria consta de una escritura de arrendamiento de una casa hecha por Diego de Soria, su nieto, pagador de la Real Chancillería, con poder de su padre, Lope de Soria, en la que se menciona al abuelo, APG, G226, 15/XII/1585.

71 AHN, Inquisición, legajo 1539, exp. 10.

72 En 1577 dice tener 77 años, AGS, Cámara de Castilla, legajo 2181, s.f.

73 Lo fue Tomás Pérez de Gadea, al que encuentro como regidor entre 1545 y 1558, ARChG, legajo 512-2473, pieza 4 y AGS, Mercedes y Privilegios, legajo 326, exp. 18.

74 Información que no consta en el testamento de su suegro, pero que sí lo hace en AGI, Pasajeros, legajo 5, pieza 784, con motivo de la marcha de su hijo Diego a Nueva España en 1567. 
pasos parecidos a los de su padre, en 1569 compraba de la Corona por dos vidas el oficio de receptor de Penas de Cámara de la audiencia granadina ${ }^{75}$. E intentó adquirir nada menos que el cargo de depositario general de la capital, a lo que el cabildo de Granada se opuso frontalmente, tanteándolo, y esgrimiendo como argumento central de su rechazo la necesidad de que «no entre en su cabildo un hombre de las calidades del dicho Lope de Soria» ${ }^{76}$.

En efecto, su condición conversa era más que notoria en la ciudad, y de ella dejó varias veces constancia la propia Inquisición, con motivo de ulteriores pruebas de sus parientes ${ }^{77}$. Pese a todo, la riqueza e influencia de su grupo de parentesco consiguió sortear los obstáculos impuestos a su ascenso social, y de forma paulatina los descendientes de Lope fueron adquiriendo honores y prestigio. Entre ellos, la condición de Correo Mayor de Granada de don Lope de Soria y Camargo ${ }^{78}$, la de racionero de la Catedral de Sevilla — con pruebas de limpieza de sangre — de don Gabriel de Soria y Camargo, en 159079, ambos hijos de Lope, y sobre todo el hábito de Calatrava que consiguió su nieto don Leonardo de Soria, quien al igual que su padre, el licenciado don Francisco de Soria y Camargo, fue veedor del presidio de Cádiz ${ }^{80}$.

Tampoco puede haber dudas de la condición conversa del ya citado arrendador Día Sánchez Dávila. Por fortuna, en este caso contamos con su propia declaración ante el tribunal del Santo Oficio, tras ser llamado a manifestar su ascendencia como descendiente de condenados ${ }^{81}$.

Gracias a este interesantísimo documento de 13 de mayo de 1529 sabemos que nuestro personaje, a la sazón jurado de la ciudad de Granada y vecino a la Puerta de Guadix, era natural de la misma urbe, nacido en torno a 1500-1501. Su padre fue Juan Dávila, mercader, vecino de Granada y en ella fallecido, y natural de Jaén o Baena, así se nos dice. Pero lo más relevante de la biografía de su progenitor es el dato de haber sido preso en la Inquisición de Córdoba en tiempos del tenebrario Lucero, siendo posteriormente liberado (seguramente por el motín que tuvo lugar en 1508, encabezado por la nobleza local) ${ }^{82}$. Su madre fue, ya se mencionó antes, Beatriz González, y fue reconci-

75 AGS, Dirección General del Tesoro, legajo 231, exp. 51.

76 AGS, Cámara de Castilla, Oficios, legajo 13, s.f.

77 Por poner un caso, AHN, Inquisición, legajo 1539, exp. 8.

78 HENRÍQUEZ DE JORQUERA, 1987, II: 728, indica que fue asesinado en febrero de 1632.

79 ADS, G-7, caja 25.

80 AHN, Órdenes Militares, Calatrava, exp. 2505. El oficio de veedor de padre e hijo (1610 y 1622, respectivamente), consta en CONCEPCIÓN, libro V, capítulo VIII.

81 La copia del documento, pues se trata de un traslado autorizado de fines del siglo XVII, la encontramos en AHN, Inquisición, legajo 1494, exp. 15.

82 Sobre la cuestión y su contexto, véanse dos interesantes artículos, EDWARDS, 1986. CUADRO GARCÍA, 2003. 
liada y luego liberada. Tanto ella como su marido, evidentemente, habían sido apresados por su condición de judaizantes.

Los abuelos de Día Sánchez Dávila tampoco carecen, precisamente, de interés en este sentido. El abuelo paterno fue Álvaro Dávila, escudero, lo que nos indica un nivel social relativamente elevado; no estamos ante menesterosos judíos dedicados antes de su conversión a tareas bajas en la escala social o económica, sino que nos hallamos ante un grupo familiar de bastante nivel, parentela afectada por la Inquisición pero que pudo recuperarse gracias a las febriles actividades económicas de sus miembros, aprovechando además, como tantas otras de su estilo, la venta de oficios para ascender en la escala social ${ }^{83}$. Y lo mismo sucede con el abuelo materno, Alvar Fernández, contador del conde de Cabra, vecino como su señor de la próspera villa de Baena, un auténtico nido de conversos $^{84}$. Este Alvar Fernández fue condenado por la Inquisición como judaizante después de muerto; es de suponer que sus huesos fueron quemados en la hoguera.

De las abuelas, casi nada se nos dice más allá de sus nombres, respectivamente Mayor González y Mayor Hernández, que parece no fueron condenadas. Más información por suerte se nos ofrece de otros colaterales. Hermanos del padre fueron Gonzalo Dávila, igualmente anotado como escudero, vecino de Granada; Diego Dávila y Aldonza Dávila, esposa de Hernando de Molina, vecinos de Úbeda. Parece que ninguno de ellos tuvo problemas con la Inquisición.

De entre sus primos hermanos hemos de destacar a Álvaro Dávila, clérigo granadino; Beatriz Dávila, mujer de Diego de Trillo, alcaide de Carcabuey (Córdoba) ${ }^{85}$; Guiomar Dávila, esposa de Cristóbal de Molina, vecinos de Baeza; o Isabel de Molina, casada con el comendador Tobilla, residentes en Úbeda.

De los hermanos de Día Sánchez Dávila, el más interesante fue Juan Rodríguez Dávila, sucesor en el mayorazgo familiar, de quien procedió una larga estirpe de caballeros veinticuatro de Granada, asimilados pronto a las filas del patriciado local, los cuales consiguieron ocultar convenientemente su sangre conversa, haciéndose pasar por descendientes de conquistadores. Lo habitual en estos casos.

83 Un modelo de lo cual se presenta en SORIA MESA, 2014b.

84 SORIA MESA y OTERO MONDÉJAR, 2014.

85 De quienes procederán una larga lista de descendientes, perfectamente integrados en la nobleza cordobesa, pero que sufrirán graves problemas para superar numerosas probanzas de limpieza de sangre (hábitos de órdenes militares, Inquisición...) hasta bien entrado el siglo XVIII. 


\section{A MOdo de CONCLUSIÓn. DE SEDEROS A NOBLES}

En los inicios de la Granada cristiana, tiempo de oportunidades como pocos hubo, encontramos la figura de Manuel de Úbeda, personaje asentado en la ciudad de Guadix desde la conquista y dedicado entre otras muchas actividades lucrativas a la administración de rentas. Arrendador de la seda, también lo fue de otros impuestos en el obispado de Málaga, todo ello en torno a 1501-1504. Nada nuevo en el seno familiar, pues ya antes había fiado a su hermano Fernando Manuel en la renta de la seda de los partidos de Almería y Marchena en 1498 y 1499. Y este último fue avalista de otro toledano, Bernardino de Píñar, esta vez en el partido de la seda de Guadix ${ }^{86}$.

Notorios conversos, como veremos a continuación, traigo aquí a esta familia no por ser muy relevante, como lo fueron los riquísimos De la Fuente, De la Torre, Hurtado de la Fuente o el plutócrata Día Sánchez Dávila, de los que ya hemos hecho mención. Los rescato del olvido precisamente debido a su relativa modestia en el concierto de estos grandes hombres de negocios. Para mostrar las formas de integración de los más llamativos cristianos nuevos en el seno de la sociedad dominante, a pesar de todas las señas de identidad grupales, que les perseguirían durante un siglo, pero que finalmente fueron vencidas por el omnímodo poder del dinero. No hacía falta para asimilarse del todo a la nobleza ser un potentado; bastaba con ser rico a nivel local para conseguirlo, acaso de forma más lenta pero ciertamente igual de efectiva.

La condición confesa de la familia salió a relucir con motivo de las muy controvertidas probanzas de hidalguía que sus descendientes litigaron en la Real Chancillería de Granada a comienzos del siglo XVII. En ellas, el fiscal de la audiencia utilizó la artillería pesada, sacando a relucir no sólo su muy evidente estatus pechero, sino incluso, lo cual no era tan habitual, la progenie hebrea de sus ancestros. El pleito lo sostuvieron los hermanos Gabriel, Francisco y Juan de Mescua, así como su primo hermano por línea masculina don Diego de Viedma, todos ellos vecinos de Úbeda aunque originarios de Guadix, descendientes concretamente de Gabriel de Úbeda, abuelo paterno de todos ellos, hermano de los mencionados Manuel de Úbeda y Fernando Manuel.

Estos tres hermanos, Gabriel y los dos arrendatarios, fueron hijos de Juan Manuel, condenado por la Inquisición en sus primeros tiempos de funcionamiento. Para más complicaciones, el propio Gabriel de Úbeda casó con Constanza de Cazorla, hija o nieta de Rodrigo de Cazorla, igualmente penitenciado por el Santo Oficio por ser judaizante.

Todo ello salió a relucir en el mentado pleito de hidalguía. Un largo y costoso suplicio legal en el que muchos testigos no dudaron en declarar que el padre de ellos, Pedro Manuel, tratante en madera,

\footnotetext{
86 GARCÍA GÁMEZ, 2007: 264
} 
compuso su incapacidad y de su mujer e hijos por 105 ducados con un comisario que con facultad real vino al partido de la dicha ciudad de Úbeda a componer semejantes incapacidades que llamaban de la farda ${ }^{87}$.

Pero si hubo testigos en contra, más y de mejor calidad fueron los que declararon a favor de los pretendientes. Por ejemplo, don Pedro de los Cobos Vela, caballero de Santiago, pariente lejano de los marqueses de Camarasa, o don Luis de Baena, regidor de Úbeda. No importaba que los sambenitos familiares hubieran colgado como horrible denuncia de la infamia en los templos locales. No se trataba de decir la verdad, sino de apoyar a uno de los suyos, hubiera además o no sobornos y regalos de por medio, como solía ser costumbre.

Porque, en efecto, los Manuel de Úbeda, que así dieron en llamarse, se habían ido convirtiendo en nobles de esa ciudad giennense, adoptando todas las formas externas que caracterizaban a la clase dirigente local. Y aspiraban a la limpieza de sangre que, a falta de auténticos méritos genealógicos, sólo podía darles el olvido y la invención del pasado.

Y para ello, hacía falta establecer buenos casamientos. Comprar novias a cambio, seguramente, de enlazar con hijas de ramas menores de la nobleza urbana carentes de dotes. Es la hipergamia consentida que tan frecuente fue en estos contextos sociales y que tanta importancia tuvo en los continuos procesos de ascenso social de estos grupos de orígenes heterodoxos ${ }^{88}$.

Gracias a su fortuna, los cuatro litigantes llegaron a ser con el tiempo caballeros veinticuatros de Úbeda, lo que les permitió asaltar la institución por excelencia del poder local y relacionarse con las grandes familias del patriciado urbano. Con tales contactos, su gran patrimonio y redes de influencia, empezaron a casarse de manera excelente.

Una estrategia como ésta culminaba inexorablemente en la consecución de la nobleza de sangre. La falsedad testifical, muchas veces aunada con la documental, permitía a este tipo de familias obtener la hidalguía. Hasta aquí, algo muy habitual en este tipo de linajes. Lo que no es tan frecuente es que, a la vez que se lanzaban a la búsqueda de la anhelada ejecutoria, los Manuel de Úbeda, desarrollaron una amplia campaña mediática, por así llamarla, conducente a consagrarse socialmente a nivel nacional.

Y para conseguir sus propósitos, nada mejor que lograr, de la forma que fuese, el apoyo de un ambicioso genealogista, Alfonso López de Haro, autor de un tratado exitosísimo, el Nobiliario genealógico de los reyes y títulos de España, que vio la luz en 1622. Utilizando los métodos que se pueden fácilmente sospechar, nuestros protagonistas consiguieron insertarse en medio de

87 ARChG, legajo 9640, pieza 14.

88 SORIA MESA, 2000. 
esta obra, enormemente difundida a lo largo y ancho de la Monarquía Hispánica ${ }^{89}$.

De esta manera, el tratadista genealógico, al que por su trayectoria no se puede definir precisamente como un dechado de honestidad ${ }^{90}$, colocó a los ubetenses en medio de las más preclaras estirpes de la aristocracia nacional, injertándolas en medio de uno de los más nobles troncos derivados de los magnates bajomedievales. Aprovechando la identidad de su apellido, y siguiendo una estrategia muy habitual entre los judeoconversos ${ }^{91}$, este linaje confeso fingió ser una rama menor de los Manuel de Castilla, como es bien sabido descendientes por varonía nada menos que del autor del Conde Lucanor, don Juan Manuel, señor de Villena, el gran príncipe de la llanura manchega, hijo del infante don Manuel y nieto del rey Fernando III de Castilla y León.

Derivados de ellos, sin la más mínima prueba documental, López de Haro, inventa a unos Manuel avecindados en Illescas, de los que procederían todos los citados, y concretamente el Manuel de Úbeda, arrendador de la Renta de la Seda, y quien ha permitido desarrollar este excurso. Concluyendo la transformación al trocar a un administrador de impuestos, comerciante y padre de un tratante en madera en un noble hijodalgo, conquistador del reino de Granada y repartido por los Reyes Católicos tras la toma de Guadix con importantes predios como el caballero que inventaron que era.

La narración anterior muestra a la perfección cómo se pasa, en el tiempo medio o en el largo, de la condición mercantil a la nobiliaria. Cómo el dinero amasado con el tráfico sedero, en el caso que nos ocupa, invertido en ostentación y adquisición de influencias y estatus, consigue limpiar poco a poco las ascendencias y transformarlas en similares a las que demandaba el ideal de la sociedad de ese momento.

No se trata de hablar de la tan traída y llevada traición de la burguesía braudeliana, concepto ya bastante obsoleto, sino de mostrar cómo la adaptación a los nuevos lenguajes sociales era un requisito imprescindible para el triunfo familiar. Y a conseguirlo se lanzaron con ímpetu las estirpes más dinámicas y preparadas, obteniendo la victoria en una incierta carrera. Las que no pudieron o supieron hacerlo, cayeron en el olvido.

Nada de extraño tiene, por tanto, que el siglo XVII ya no sea la centuria conversa que fue el Quinientos en relación a la seda granadina. Las circunstancias habían cambiado, y con ellas lo hicieron los protagonistas del arrendamiento de tan lucrativa renta. Pero no fueron únicamente éstas las causantes, como por lo general se ha afirmado. No todo consistió en factores exógenos, como la decadencia de la Monarquía, la despoblación, los cambios

89 LÓPEZ DE HARO, 1622, I: 53-56.

90 Una breve semblanza, a falta de una biografía definitiva, en SORIA MESA, 1997b.

91 SORIA MESA, 2009. 
en la fiscalidad o la guerra de las Alpujarras y la posterior expulsión de los moriscos.

En este cambio de orientación tuvo que ver, al menos tanto como la suma de los anteriores ítems, la transformación social experimentada, tras largas décadas, por los conversos que habían acostumbrado a tomar para sí la renta sedera. Es por esto por lo que se acaba el monopolio cristiano nuevo, entre otras cosas porque ya no quedaban casi conversos entendidos como tales. Habían dejado de ser una comunidad, disolviéndose en el seno de la sociedad dominante, entrando casi todos ellos por la puerta grande gracias al poder del dinero y a las necesidades del Estado Moderno.

Así sucedió con todas las grandes familias implicadas en el tráfico sedero. Antes o después, pues hubo variaciones en los tiempos como es lógico, el proceso de ennoblecimiento les fue llevando a cambiar de horizontes. No a dejar las prácticas económicas, sería una banalidad expresarlo así, sino a girar de rumbo su política inversora.

Y para encontrar los respectivos hitos en la evolución de cada grupo de parentesco nada hay mejor, puesto que no existen fechas exactas ni mucho menos en lo que fue un proceso lento y pausado, que analizar las posibles alteraciones en las estrategias matrimoniales. Los muy planificados casamientos pueden servir de excelente atalaya desde la que otear un posible cambio de tendencia, a veces manifestado de forma brusca, otras de manera tan suave que cuesta apreciarlo.

Es el caso de los De la Fuente, los Alcocer, los Cepeda, los Velluga Moncada, San Pedro... Entre otros muchos. La primera clave nos la ofrece precisamente el abandono de las relaciones, al menos visiblemente, con la antigua metrópoli toledana. Cesan los casamientos con parientes, lo mismo que parece disminuir el negocio directo con esa ciudad. O cuando menos lo hace su reflejo en las actas notariales. Los antaño toledanos se han convertido para siempre en granadinos de pura cepa.

Más importante aún, o eso me parece, son los casamientos exogámicos que empiezan a aparecer en el seno del colectivo. Poco a poco se va enlazando, según las posibilidades de cada cual, con miembros de la mesocracia burocrática o comercial, meros hidalgos o nobles de rango medio. Y lo que al principio se ve como excepción, pronto es una avalancha que crea norma y al tiempo es la única forma de desposorio que se admite. La endogamia no desaparece del todo, pero la que tiene lugar no es otra cosa que la propia de los grupos nobles - ennoblecidos en nuestro caso- que desposan a sus primas más o menos lejanas. Ya no lo hacen con la saña de los tiempos pasados, cuando lo que estaba en juego era no perder la conciencia de pertenecer a un mismo colectivo sanguíneo y cultural.

Veamos el caso de la parentela de Melchor de Cepeda, mercader de seda, toledano como no podía ser menos en un pariente cercano de Santa Teresa de 
Jesús. Llegados desde la urbe castellana él y su hermano Baltasar, entre sus respectivas descendencias se establecen casamientos consanguíneos, que llegan a su cénit en 1604. Luego, pasan a un segundo plano o directamente desaparecen.

Por otro lado, si Melchor, que vivió a mediados del siglo XVI fue mercader, sus hijos Alonso y Álvaro aparecen siempre en la documentación con el cargo de capitán, este último llamado habitualmente el capitán Cepeda de Ayala, pues pocas veces usa de su nombre propio. Este interesante personaje, caballero veinticuatro de Granada y muy rico, casó con una ilustre dama local, miembro de una rama venida a menos de un preclaro linaje, doña Paula Porcel de Peralta, hermana de un caballero de Santiago.

Asentada la progresión familiar con esta excelente boda, lo demás fue relativamente sencillo. De los hijos de esta coyunda, don Juan fue caballero de Calatrava en 1639, y don Luis, el primogénito, lo fue de la de Santiago, además de veinticuatro de Granada, señor de la villa de Cozvíjar y alguacil mayor del Santo Oficio, todo ello tras pasar unas controvertidas pruebas de limpieza de sangre en donde algunos enemigos del linaje se despacharon a gusto contra sus calidades. Nada que pudiera detenerlos. Tanto es así, que de don Luis descenderán los condes de Villamena, próceres locales de la Granada de los siglos XVII y XVIII ${ }^{92}$.

Podríamos hablar aquí de los Alcocer, de los San Pedro, convertidos éstos en caballeros veinticuatros en el siglo XVII, y de muchos más apellidos, relacionados todos ellos con el tráfico sedero o con el arrendamiento del impuesto pertinente. Pero me limitaré a traer a colación someramente el caso de los De la Fuente, en varias de sus líneas. Una de ellos, los parientes de la mujer de Día Sánchez Dávila, quienes tras la extinción de la descendencia de esta pareja heredaron el señorío de Cázulas, cerca de la costa granadina. En ellos encontraremos a lo largo de los siglos XVII y XVIII una saga de regidores de la capital, acabando en la Casa de Afán de Rivera, emparentada con lo más granado del patriciado local.

O los mismos Dávila del mencionado Día Sánchez, quienes dejaron las tareas mercantiles por la gestión de los propios mayorazgos, terminando la línea dimanada de su hermano Juan Rodríguez Dávila en diversas estirpes locales, conformando su árbol genealógico una plétora de regimientos, hábitos de órdenes militares y algún que otro título del reino.

Es el fin de la conciencia de grupo. El abandono de la comunidad conversa a favor de la individualidad cristiano vieja, no por falsa e inventada menos efectiva en cuanto que asumida por casi todos ellos como el destino obligado en una sociedad como la española del Siglo de Oro.

\footnotetext{
92 SORIA MESA, 2014b.
} 


\section{BibLiOgRAFÍA}

Alonso García, David, «Entre Granada y Castilla. La familia Fuente y la hacienda real a comienzos de la Edad Moderna», Investigaciones Históricas. Épocas Moderna y Contemporánea, 25 (Valladolid, 2005), 11-30.

Bejarano Robles, Francisco, La industria de la seda en Málaga durante el siglo XVI, Madrid, Instituto de Economía Sancho de Moncada, 1951.

Cabrera Sánchez, Margarita, La medicina en Córdoba durante el siglo XV, Córdoba, Universidad de Córdoba, 2002.

Carande Thovar, Ramón, Los banqueros de Carlos V, Barcelona, Crítica, 1977.

Carretero Zamora, Juan, y Alonso García, David, Hacienda y negocio financiero en tiempos de Isabel la Católica. El libro de hacienda de 1503, Madrid, Editorial Complutense, 2003.

Casey, James, Familia, poder y comunidad en la España Moderna. Los ciudadanos de Granada (1570-1739), Valencia, Universidad de Valencia, 2008.

Castillo Fernández, Javier y Muñoz Buendía, Antonio, «La Hacienda», en Manuel Barrios Aguilera (ed.), Historia del Reino de Granada. II. La época morisca y la repoblación (1502-1630), Granada, Universidad de Granada-Legado Andalusí, 2000; 101-177.

Coronas Tejada, Luis, Conversos and Inquisition in Jaén, Jerusalén, Hebrew University, 1988.

Cuadro García, Ana Cristina, «Acción inquisitorial contra los judaizantes en Córdoba y crisis eclesiástica (1482-1508)», Revista de Historia Moderna, 21 (Alicante, 2003), 11-28.

Edwards, John, "Trial on an Inquisitor. The dismissal of Diego Rodríguez Lucero, inquisidor of Córdoba in 1508», The Journal of Ecclesiastical History, 37 (Cambridge, 1986), 240-257.

Galán Sánchez, Ángel, «Herejes consentidos. La justificación de una fiscalidad diferencial en el reino de Granada», Historia. Instituciones. Documentos, 33 (Sevilla, 2006), 173-209.

García Gámez, Félix, «La seda del Reino de Granada durante el segundo proceso repoblador (1570-1630)», Chronica Nova, 25 (Granada, 1998), 249-273.

García Gámez, Félix, «Seda y repoblación en el Reino de Granada durante el tránsito de los siglos XVI y XVII», Chronica Nova, 28 (Granada, 2001), 221-255.

García Gámez, Félix, «Asaltar la renta. Caos y conflicto en la administración de la renta de la seda del Reino de Granada a inicios del siglo XVII (1600-1608)», Chronica Nova, 30 (Granada, 2003-2004), 103-155.

García Gámez, Félix, «La renta de la seda del Reino de Granada durante el siglo XVII. Balance y perspectivas de estudio», en Manuel Barrios Aguilera y Ángel Galán Sánchez (eds.), La historia del reino de Granada a debate. Viejos y nuevos temas. Perspectivas de estudio, Málaga, Diputación Provincial, 2004; 263-280.

García Gámez, Félix, «La renta de la seda del reino de Granada y sus arrendadores en el Marquesado de los Vélez en época mudéjar (1490-1504)», en Andújar Casti- 
1lo, Francisco y Díaz López, Julián Pablo (eds.), Los señoríos en la Andalucía Moderna. El Marquesado de los Vélez, Almería, Instituto de Estudios Almerienses, 2007; 257-265.

García Ivars, Flora, La represión en el tribunal inquisitorial de Granada, Madrid, Akal, 1991.

García Pedraza, Amalia, Actitudes ante la muerte en la Granada del siglo XVI. Los moriscos que quisieron salvarse, Granada, Universidad de Granada, 2002.

García Pedraza, Amalia, «De agentes fiscales a vizcondes, de conversos a teólogos. Los primeros años de los Suárez Toledo en Granada», en Julián Pablo Díaz López, Francisco Andújar Castillo y Ángel Galán Sánchez (eds.), Casas, familias y rentas. La nobleza del reino de Granada entre los siglos XV-XVIII, Granada, Universidad de Granada, 2010; 237-257.

Garrad, Kenneth, «La industria sedera granadina en el siglo XVI y en conexión con el levantamiento de la Alpujarra, 1568-1571», Miscelánea de Estudios Árabes y Hebraicos, V (Granada, 1956), 73-104.

Garzón Pareja, La industria sedera en España. El arte de la seda de Granada, Granada, Archivo de la Real Chancillería de Granada, 1972.

Gil, Juan, Los conversos y la Inquisición sevillana, Sevilla, Universidad de SevillaFundación El Monte, 2000-2003, 8 vols.

Gómez-Menor Fuentes, José Carlos, El linaje familiar de Santa Teresa y de San Juan de la Cruz. Sus parientes toledanos, Toledo, Gráficas Cervantes, 1970a.

Gómez-Menor Fuentes, José Carlos, Cristianos nuevos y mercaderes de Toledo, Toledo, Gráficas Cervantes, 1970b.

Henríquez de Jorquera, Francisco, Anales de Granada, Granada, Universidad de Granada, 1987, 2 vols.

Jerónimo de la Concepción, Emporio del Orbe, ed. de Arturo Morgado García, Cádiz, Universidad de Cádiz, 2003.

Ladero Quesada, Miguel Ángel, «Rentas de Granada», en Ladero Quesada, Miguel Ángel, Granada después de la conquista. Repobladores y mudéjares, Granada, Diputación Provincial, 1988; 261-271.

López Beltrán, María Teresa, «Redes familiares y movilidad social en el negocio de la renta. El tándem Fernando de Córdoba-Rodrigo Álvarez de Madrid y los judeoconversos de Málaga», Revista del Centro de Estudios Históricos de Granada y su Reino, 24 (Granada, 2012), 33-72.

López de Coca Castañer, José Enrique, «La fiscalidad mudéjar en el reino de Granada», en Actas del V Simposio Internacional de Mudejarismo, Teruel, Instituto de Estudios Turolenses, 1991; 191-219

López de Coca Castañer, José Enrique, «La seda en el reino de Granada (siglos XV y XVI)», en España y Portugal en las rutas de la seda. Diez siglos de producción y comercio entre Oriente y Occidente, Barcelona, Universidad de Barcelona, 1996; 33-57.

López de Haro, Alfonso, Nobiliario genealógico de los reyes y títulos de España, Madrid, imprenta de Luis Sánchez, 1622. 
Malpica Cuello, Antonio, Quesada Quesada, Tomás, y Rueda Llorca, José María, Colección Diplomática del archivo de la Casa de Cázulas (1368-1520), Granada, Instituto Provincial de Estudios y Promoción Cultural, 1982.

Martz, Linda, «Los toledanos y el reino de Granada, 1492-1570», en Richard Kagan y Geoffrey Parker (eds.), España, Europa y el mundo atlántico. Homenaje a John Elliott, Madrid, Marcial Pons, 2001; 151-176.

Martz, Linda, A Network of Converso Families in Early Modern Toledo. Assimilating a Minority, University of Michigan, Ann Arbor, 2003.

Miralles Martínez, Pedro, La sociedad de la seda. Comercio, manufactura y relaciones sociales en Murcia durante el siglo XVII, Murcia, Universidad de Murcia, 2002.

Montemayor, Julián, «La seda de Toledo en la Época Moderna», en España y Portugal en las rutas de la seda. Diez siglos de producción y comercio entre Oriente y Occidente, Barcelona, Universidad de Barcelona, 1996; 120-132.

Moreno Garzón, Luis, Jiménez Alarcón, Margarita y Parra Arcas, María Dolores, El Manuscrito de los Caballeros XXIV de Granada, Granada, Ayuntamiento de Granada, 1986.

Moreno Trujillo, Amparo, «Las actuaciones de la Inquisición y los escribanos judeoconversos del entorno del conde de Tendilla», Historia. Instituciones. Documentos, 37 (Sevilla, 2010), 181-210.

Palencia Herrejón, Juan Ramón, Ciudad y oligarquía de Toledo a finales del medievo (1422-1522), Tesis Doctoral, Madrid, Universidad Complutense, 1999.

Pérez de Herrasti, Juan Francisco de Paula, Historia de la Casa de Herrasti, señores de Domingo Pérez, (edición de María Julieta Vega García-Ferrer; estudio preliminar de Enrique Soria Mesa), Granada, Editorial Universidad de Granada, 2007.

Porras Arboledas, Pedro Andrés, Las comunidades conversas de Úbeda y Baeza en el siglo XVI, Jaén, Instituto de Estudios Giennenses, 2008.

Rodríguez de Gracia, Hilario, «Mercaderes y asociaciones mercantiles en el comercio toledano de la seda de la segunda mitad del siglo XVII», Hispania, 210 (Madrid, 2002), 65-112.

Santos Vaquero, Ángel, La industria textil sedera de Toledo en el siglo XVIII, Madrid, Tesis Doctoral, 1998.

Santos Vaquero, Ángel, «Ordenanzas del gremio del arte mayor de la seda de Toledo», Docencia e Investigación, 19 (Toledo, 2009), 223-262.

Soria Mesa, Enrique, Señores y oligarcas. Los señoríos del reino de Granada en la Época Moderna, Granada, Universidad de Granada, 1997a.

Soria Mesa, Enrique, La biblioteca genealógica de don Luis de Salazar y Castro, Córdoba, Universidad de Córdoba, 1997b.

Soria Mesa, Enrique, «Los judeoconversos granadinos en el siglo XVI: Nuevas fuentes, nuevas miradas», en Antonio Luis Cortés Peña y Miguel Luis LópezGuadalupe (eds.) Estudios sobre Iglesia y Sociedad en Andalucía en la Edad Moderna, Granada, Universidad de Granada, 1999; 101-109.

Soria Mesa, Enrique, El cambio inmóvil. Transformaciones y permanencias en una elite de poder (Córdoba, siglos XVI-XIX), Córdoba, Ayuntamiento de Córdoba, 2000. 
Soria Mesa, Enrique, «Burocracia y conversos. La Real Chancillería de Granada en los siglos XVI y XVII», en Francisco José Aranda Pérez (coord.), Letrados, juristas y burócratas en la España Moderna, Cuenca, Universidad de Castilla-La Mancha, 2005; 107-144

Soria Mesa, Enrique, La nobleza en la España Moderna. Cambio y continuidad, Madrid, Marcial Pons, 2007.

Soria Mesa, Enrique, «Tomando nombres ajenos. La usurpación de apellidos como estrategia de ascenso social en el seno de la élite granadina durante la Época Moderna», en Enrique Soria Mesa, Juan Jesús Bravo Caro y José Miguel Delgado Barrado (coords.), Las élites en la Época Moderna: la Monarquía Española, I, Visiones generales, Córdoba, Universidad de Córdoba, 2009; 9-28.

Soria Mesa, Enrique, «De la represión inquisitorial al éxito social. La capacidad de recuperación de los judeoconversos andaluces entre los siglos XV-XVII: el ejemplo del linaje Herrera», Medievalismo, 24 (Madrid, 2014a), 399-417.

Soria Mesa, Enrique, Genealogías del Reino de Granada. Tomo I, Granada, 2014b (en prensa).

Soria Mesa, Enrique y Otero Mondéjar, Santiago, «Los judeoconversos de Baena (siglos XV-XVII). Rechazo e integración social», Ituci, 4 (Baena, 2014), 95-106.

Torres Fernández, María del Rosario, «Algunas consideraciones sobre la industria de la seda en Almería en el siglo XVI», en Catalina Martínez Padilla (coord.), A la memoria de Agustín Díaz Toledo, Almería, Universidad de Almería, 1995; 405416.

Vera Delgado, Ana María, «El levantamiento mudéjar y su incidencia en la percepción de los tributos de la seda», en III Simposio Internacional de Mudejarismo, Teruel, Instituto de Estudios Turolenses, 1986; 145-152.

Ulloa, Modesto, La hacienda real de Castilla en el reinado de Felipe II, Madrid, Fundación Universitaria Española, 1977.

Recibido: $27 / 05 / 2014$

Aprobado: 29/12/2015 